\title{
Sztuka książki w warsztatach drukarzy warszawskich w XVII I XVIII wieku
}

odjęty temat ma bardzo szeroki zakres dociekań naukowych, natomiast dotychczasowy stan badań historiograficznych oraz stopień rozpoznania bogatego materiału źródłowego nie stanowi podstawy do formułowania wniosków syntetycznych. Stąd w niniejszym opracowaniu rozwinięte zostanie zagadnienie uwarunkowania rozwoju książki wytwarzanej w nowym mieście rezydencjonalnym królów Rzeczypospolitej - Warszawie, z przydaniem propozycji dokumentowania danych dotyczących poziomu typograficznego druków.

Czarna sztuka jest elementem sztuki. Definicja tejże sztuki pozostaje niejednoznaczna, specjaliści bowiem mogą adaptować ją stosownie do potrzeb, przyjętego zakresu badawczego, z czego też wynika potrzeba interpretacji tego terminu stosownie do potrzeb bibliologii. Ponieważ nie sposób mówić o sztuce książki wyłącznie w Warszawie, rozważania ukierunkowane na to zagadnienie rozpocznę od problematyki o charakterze ogólnym.

Już od czasów Johanna Gensfleischa zum Gutenberg umiejętność odlewu czcionki odpowiedniego kroju, dopasowania koloru jej odcisku do barwy podłoża oraz uzupełniania zdobnictwem według oczekiwanych lub przewidywanych potrzeb wynikajacych z wrażliwości estetycznej odbiorcy stanowiły o konieczności posiadania przez wykonawcę talentu artystycznego. Grafika artystyczna bowiem nie tylko zadecydowała o naśladującym dukt pisma ręcznego kształcie liter zawartych $w$ czcionce, lecz szybko znalazła zastosowanie również $w$ zdobnictwie oraz ilustracji, bazując zrazu na dwóch podstawowych technikach - drzeworycie i miedziorycie - stała się ściśle związana ze sztuką książki drukowanej.

Formalnie przez sztukę książki drukowanej rozumieć należy zespół czynności edytorskich i typograficznych z uwzględnieniem elementów estetyki, które w efekcie czynią z bloku książkowego dzieło sztuki mogące stanowić odzwierciedlenie obowiązujących w danym czasie kanonów stylistycznych w sztukach plastycznych lub poza nie wykraczających.

W ten sposób tworzono książkę artystyczną, obecnie zwaną niekiedy piękną. 
Wśród dzieł modelowych można dostrzec przestrzeganie klasycznej zasady zgodności wyrazu artystycznego w literaturze i w sztuce.

Ważne miejsce w estetyce zajmuje karta lub strona tytułowa, zawierająca tytulaturę dzieła. Na tytulaturę składa się ogół zapisów informujących o dziele, a więc nazwisko autora, tytuł oraz adres wydawniczy. Jej kształt podlegał zmianom, których zakres pozostawal uwarunkowany $z$ jednej strony umasowieniem wytwarzania tekstów przy zastosowaniu techniki druku, z drugiej strony zaś konsekwencja stylistyczną, wynikającą z wyżej wspomnianej zasady zgodności wyrazu artystycznego.

Forma i treść tytulatury dziela zróżnicowana była ze względu na przewidzianą dla niej rolę, jaką miała do spełnienia. Tytulatura bowiem mogła po prostu informować o treści dzieła oraz o jego autorze, ale także można było jej nadać formę tzw. rynkową, stanowiącą zachętę do zakupu publikacji, czyli spełniała funkcję wynikająca z potrzeb reklamy wydawniczej, a ponadto mogła być formą uroczystej dedykacji np. w wydawnictwach panegirycznych. To zróżnicowanie funkcji powodowało, że karcie tytułowej zwykle nadawano najbardziej staranną kompozycję typograficzna, niejednokrotnie na artystycznym poziomie wyrazu plastycznego.

Specjalne i obszerne zagadnienie przedstawia sobą tytulatura periodyków, której analiza naukowo-badawcza jest niezbędna dla wydobycia obrazu kształtowania się cech wydawniczych czasopism staropolskich ${ }^{1}$.

Bez wątpienia bardzo istotny jest również papierologiczny kierunek badań. Jakość, grubość, barwa oraz jednorodność papieru decydowały przecież o poziomie wyrazu estetycznego tłoczenia i zdobieniu tekstu. Ważne są tu badania filigranistyczne i dociekania, czy papier był pochodzenia rodzimego, czy też importowany.

O urokliwości, czyli zewnętrznym, z czasem też reklamowym pięknie książki zadecydowała oprawa, od czasów nabrania cech wydawniczych potocznie zwana okładką.

Wprawdzie jeszcze w 1725 r. Krzysztof Różycki, znany księgarz warszawski i krakowski, a zarazem introligator-amator w swym Summariuszu stwierdzał: Nie jest to kunszt księge zrobić $i$ dobrze oprawić ${ }^{2}$, niemniej właśnie introligatorstwo, jako jedyne związane z wytwarzaniem książki, znajdowało się na staropolskiej liście rzemiosl, pomijającej kartowników o niezbyt precyzyjnym zakresie reprezentowania umiejętności ${ }^{3}$. Choć już w XVI w. pracowali w Warszawie introligatorzy, cech introligatorski zaistniał tu dopiero na początku XVIII w. Warto podkreślić, że strukturalnie był on podporządkowany krakowskiemu cechowi, z czego wynikaly wspólne dla obu ośrodków ustalenia regulujące zasady współpracy introligatorów z drukarzami ${ }^{4}$. Monopolistyczne zaś, w zakresie handlowego obrotu książką, na niekorzyść drukarzy, zapędy cechowych introligatorów zostały powstrzymane dopiero przez Augusta II Sasa, który w 1725 r. zapewnil, iż drukarze i księgarze pod- 
legają jedynie sądownictwu Akademii Krakowskiej i króla. Drukarzom odtąd zagwarantowano prawo sprzedaży wydawnictw własnych - introligatorzy zaś czynić tego nie powinni, gdyż ich zadaniem jest oprawa książek, a nie handel nimi ${ }^{5}$.

Stanowi to dodatkowe uzasadnienie merytorycznej rozdzielności dokonywania analizy naukowej bloku książkowego i jego oprawy. Należy podkreślić, że o kształcie oprawy decydował przede wszystkim nabywca ksiażki, czyli jej właściciel. Oprawa introligatorska bowiem, w odróżnieniu od wydawniczej, powstawala na wyraźne zamówienie nabywcy surowego bloku ksiażkowego i z rzadka możemy archiwalnie udowodnić, że dana oprawa jest wydawnicza, choć sporadycznie takie oprawy zaistniały, ale w wyniku wcześniejszych ustalen między autorem, nakladca i wydawcą. Najczęściej natomiast praktykowano proste zbroszurowanie w okładzinie zwanej alla rustica. Wobec tego, z naukowego punktu widzenia należy oddzielnie analizowac oprawę oraz sam blok książkowy, są to bowiem zazwyczaj dwa różne fakty historyczne, często posiadające różną chronologię (zdarzaly się też przeoprawienia) i różne warsztaty twórców. Stanowi to proweniencyjny materiał źródłowy najczęściej pomijany przez niedoświadczonych badaczy i dokumentalistów. Odczytywane bywają one łącznie, czyli w sposób niewłaściwy, prowadzący do błędnych wniosków.

Gdy 12 lipca 1624 r. Zygmunt III Waza powołał Jana Rossowskiego z Poznania na uprzywilejowanego drukarza Rzeczypospolitej, był świadomy faktu, że Warszawa znacznie wcześniej wyraziła swe zamówienie społeczne na słowo drukowane, któremu w latach 1578-1581 musial sprostać Walenty Łapczyński, prowadzacy drukurnię latajacq we współpracy ze znanym krakowskim drukarzem Mikołajem Szarfenbergerem ${ }^{6}$.

Te wcześniejsze druki warszawskie, mimo zastosowanej techniki tłoczenia (szwabacho-fraktura i antykwa) z przydaniem zdobnictwa drzeworytowego, nie stanowią odwzorowania wysokiego, niejednokrotnie europejskiego poziomu krakowskiego drukarstwa czasów Odrodzenia. Niemniej atmosfera nowo kreowanego przez króla stałego ośrodka drukarstwa w Warszawie powinna sprzyjać rozkwitowi ambicji zdystansowania konkurencyjnego Krakowa pod względem czarnej sztı$k i$. Dotąd pozostaje historiograficznie nierozstrzygnięte uzasadnienie faktu sprowadzenia do Warszawy drukarza z Poznania, z pominięciem moźliwości przeniesienia tu choćby jednej ze znakomitych oficyn krakowskich. Monografista drukarni Jana Rossowskiego stwierdza, że został on przez pewnych doradców polecony królowi... i jednocześnie akcentuje bardzo wymowne, w rozwoju drukarstwa urzędowego, utrzymanie równoleglego uprzywilejowania w tym zakresie krakowskich oficyn drukarskich? ${ }^{7}$. Warto przypomnieć, że w 1661 r. przybył z Krakowa do Warszawy Jan Aleksander Gorczyn, drukarz rytownik, zajmujący się między innymi wydawaniem „Merkuriusza Polskiego”. Zapewne zwiedziony nadzieją zainteresowania pe- 
riodykiem ogólnoinformacyjnym w mieście rezydencjonalnym dworu królewskiego - uruchomił oficynę własną i wytloczył tu 14 numerów gazety ${ }^{8}$. Skromne wyposażenie techniczne warsztatu znalazło wyraz w stosunkowo niskim poziomie wykonawstwa druku przy zastosowaniu mało estetycznej gotyko-antykwy i antykwy.

Przedsięwzięcie Gorczyna okazało się efemerydą i był on zmuszony powrócić do Krakowa.

Wobec powyższego można domniemywać, że organizujący się dwór królewski w Warszawie nie uznał za stosowne specjalnie wyróżnić któregoś z zasłużonych drukarzy krakowskich, podkreślając tym samym dążność do utrwalenia stołecznej rangi Krakowa lub też do tworzenia nowej rzeczywistości administracyjnej państwa. Na podkreślenie zasługuje fakt, że do końca XVII w., a dokładniej do uruchomienia drukarni przez ojców jezuitów w 1716 r., administracja królewska utrzymywała w Warszawie tylko jedną, opartą na serwitoriacie, tłocznię urzędową. Natomiast druki urzędowe były tłoczone przy zastosowaniu podobnych rozwiązań wydawniczo-typograficznych w Warszawie i w Krakowie 9 .

Fakt, że wczesne oficyny warszawskie pełniły przede wszystkim funkcję tłoczni urzędowych, bez wątpienia zadecydował o swoistej prostocie wyrazu estetycznego druków. Jan Rossowski, przybywając do Warszawy, miał kilkuletni staż uprawiania drukarstwa w Poznaniu i konkurencyjnego zmagania się z renomowaną oficyną Jana Wolraba młodszego. Dysponował on zestawami czcionki antykwowej, szwabachy, a nawet greki, jak również rozmaitymi ozdobnikami oraz kilkoma seriami inicjałów prostych i ozdobnych; ponadto stosował kilka rodzajów winiet. Tekst druku zestawiał przy użyciu szwabachy i antykwy; tłoczył zaś niejednokrotnie dwubarwnie - obok czerni stosował czerwień. Ilustrował drzeworytami i miedziorytami.

Spośród kolejno rozpoczynających w Warszawie działalność oficyn: Jana Trelpińskiego, Piotra Elerta oraz Karola Ferdynanda Schreibera - poziomem estetycznym pozytywnie wyróżniały się druki z warsztatu, należącego do uprzywilejowanego przez Władysława IV jego nadwornego muzyka Piotra Elerta - zięcia znakomitego drukarza krakowskiego Andrzeja Piotrkowczyka młodszego. Żona Elerta, Maria Elżbieta, wniosła w wianie otrzymane od ojca wyposażenie drukarni.

W drukach elertowskich w znacznej mierze używana była antykwa - zróżnicowana co do kroju i stopnia, choć nie zrezygnowano ze stosowania fraktury. Przykład umiejętności typograficznych stanowic tu może wydany w 1643 r. Gościniec albo krótkie opisanie Warszawy... pióra Adama Jarzębskiego ${ }^{10}$.

Na wykupionych od spadkobierców częściach tego, pozostającego na wysokim poziomie technicznym, wyposażenia drukarni - rozwinął swą działalność kolejny uprzywilejowany drukarz urzędowy K.F. Schreiber, który wcześniej pracowal w oficynie prowadzonej przez wdowę Elertową. Z jego warsztatu w 1688 r. wyszło spod pras dzieło Stanisława Herakliusza Lubomirskiego Mirobulii Tassalini Adver- 
biorum moralium sive De virtute et fortuna libellus... ilustrowane 16 miedziorytami wykonanymi przez Tylmana z Gameren, a sztychowanymi przez H.J. Helwiga ${ }^{11}$.

Część wyposażenia drukarni poelertowskiej wykupili również ojcowie pijarzy, którzy po śmierci Schreibera zadbali o skompletowanie całości wyposażenia, a w 1689 r. nabyli prawa wlasności oficyny, z nadanym jej uprzywilejowaniem. Druki pijarów warszawskich, pod względem estetyki wykonania, pozostawaly na przeciętnym poziomie. Podobnie innym oficynom zakonnym, kładziono nacisk na możliwie niski koszt produkcji; utrzymując wymóg zagwarantowania dobrej czytelności tekstu tłoczonego na niejednokrotnie kiepskim jakościowo papierze. Poslugiwali się oni czcionką pochodzenia krajowego i zagranicznego, a także odlewaną w giserni własnej. Drukarnia pijarów - jako jedyna spośród powstałych w XVII-wiecznej Warszawie - kontynuowala działalność w XVIII w.

Zasadniczo, dopiero wiek XVIII, a w szczególności czasy stanisławowskie przyniosły ilościowy i jakościowy rozkwit typografii warszawskiej. Już jednak August III Sas zwiększył liczbę uprzywilejowanych warsztatów typograficznych, gdy podzielil między pijarów i jezuitów serwitoriat na druki urzędowe i uprawnienia do wydawania czasopism; a następnie - założonej w 1756 r. przez Wawrzyńca Mitzlera de Kolofa - przyznał tytuł drukarni króla i Rzeczypospolitej. W oficynie Mitzlera pracowano na dobrym sprzęcie sprowadzonym z Lipska, od 1763 r. zaś rozpoczęto produkcję czcionek w odlewni własnej.

Interesujaca wydaje się ocena poziomu typograficznego licznych inicjatyw wydawniczych związanych z Biblioteką Załuskich, jakie realizowały się we wspólpracy z oficynami wydawniczo-drukarskimi ojców pijarów oraz Mitzlera de Kolofa. Wziąwszy pod uwagę publikacje najdonioślejsze, takie jak kodyfikujące prawo polskie (a wydawane przez pijarów) Volumina Legum (tomy 1-8, 1732-1782) czy też nie mniej pomnikową mitzlerowską serię dzieł kronikarzy polskich Historiarum Poloniae et Magni Ducatus Lithuaniae scriptorum... collectio magna ... (tomy 1-5, 1761-1777), a także siedemnaście dzieł wydanych u Mitzlera nakładem Towarzystwa Literatów w Polsce ustanowionego dla wydawania najlepszych i najpożyteczniejszych krajowi ksiażek - nasuwa się wniosek, iż nie przedstawiały one sobą wydawnictw na oczekiwanym poziomie estetyki wykonania; niemniej jednak owa estetyka mieścila się w konwencji barokowej.

Niewątpliwie Oświecenie stanisławowskie uczyniło z Warszawy główny ośrodek drukarstwa w terytorialnie zmniejszającej się Rzeczypospolitej. W roku rozpoczęcia obrad Sejmu Wielkiego (1788) na terenie miasta dzialało siedem oficyn, a wśród nich dwie o najwyższym stopniu rozwoju potencjału produkcyjnego - Piotra Dufoura i Michała Groella. Większość druków spod ich pras wychodzących pozostawała na niekwestionowanie wyższym poziomie estetyki niż wytwarzane w pozostałych warsztatach. Dominowała wprawdzie czcionka angiel- 
ska i francuska - niemniej od 1772 r. działa na szeroką skalę gisernia uruchomiona przez Adama Gieryka Podebrańskiego, który poza czcionką rozmaitego kroju oferował również ozdobniki typograficzne. Jego uczeń i późniejszy znakomity drukarz Piotr Zawadzki deklarował umiejętność wykonania czcionki każdego kroju i zapewniał o możliwości zaspokojenia ogólnokrajowych potrzeb w tym zakre$\mathrm{sie}^{12}$. Wprawdzie, ze względu na wysoką cenę produktu krajowego, drukarze warszawscy niezmiennie praktykowali zakup składów czcionek (podobnie jak i papieru) przede wszystkim poza granicami kraju - niemniej mieli do wyboru dobrej jakości produkt rodzimy ${ }^{13}$.

Liczne elementy zdobnicze również w większości pochodziły z importu - choć rozwój sztycharstwa warszawskiego był w stanie zaspokoić potrzeby. W stolecznej Warszawie, obok profesjonalnych rytowników, także malarze deklarowali się często jako peintre-graveur. Grafika artystyczna bowiem od wieków znajdowała szerokie zastosowanie w zdobnictwie oraz w ilustracji książkowej. Kadrę tych artystów plastyków stanowili przede wszystkim cudzoziemcy. Jednym z mistrzów w tej dziedzinie był, utrzymujący kontakty z biskupem J.A. Załuskim, Niemiec - G.J. Marstaller, który prowadził zespołowy warsztat rytowniczy i m.in. wykonywał winiety z sygnetem wydawniczym M. Groella ${ }^{14}$.

Mimo znakomitej kondycji ilościowej i jakościowej drukarstwa warszawskiego oraz wystarczających możliwości produkcyjnych - na przestrzeni lat 1788-1792, w atmosferze politycznej Sejmu Czteroletniego uruchomiono aż pięć nowych warsztatów. Znamienne, że założycielami tychże byli nie cudzoziemcy, lecz Polacy - i to będący przedstawicielami stanu szlacheckiego, a wśród nich tylko Piotr Zawadzki był mistrzem czarnej sztuki.

Niewątpliwie korzystnie wyróżniały się druki wychodzące spod pras należącej do Zawadzkiego Drukarni Nowej Jego Królewskiej Mości, a także Drukarni Wolnej, będącej własnością Jana Potockiego oraz Drukarni Gazety Narodowej i Obcej założonej przez Tadeusza Antoniego Mostowskiego. Druki te utrzymane byly w konwencji estetycznego kanonu klasycystycznego, polegającego na oszczędnym gospodarowaniu zdobnictwem na korzyść znacznie tańszego, a jednocześnie nowocześniejszego sposobu wydobycia oryginalnego piękna typograficznego, wynikającego z czerni odbicia czcionki szlachetnego kroju oraz odpowiedniej barwy papieru $^{15}$.

Przedstawione w niniejszym opracowaniu zagadnienia uwarunkowan rozwoju sztuki książki w Warszawie w XVII i XVIII w. wymagaja prowadzenia systematycznych i szczegółowych badań licznie zachowanego w archiwach, bibliotekach i muzeach materiału źródłowego. Bardzo ważny kierunek badań stanowi tu analiza poziomu typograficznego poszczególnych wydań druków, będących produktem określonej oficyny. Badacz musi mieć na uwadze fakt, że układ kolumny druku, dobór 
krojów czcionki oraz technika zestawiania układów zdobniczych są umiejętnościami zindywidualizowanymi - charakterystycznymi dla poszczególnych warsztatów typograficznych. Temu celowi, jak również badaniom komparatystycznym w tym zakresie służy dokumentowanie materiału faktograficznego - najlepiej przy zastosowaniu odpowiednio sformatowanej karty dokumentacyjnej (patrz s. 77) ${ }^{16}$.

W glówce karty dokumentacyjnej znaleźć się powinny następujące dane: data druku, nazwa drukarni, miejsce druku; następnie zaś informacje o autorze, tytule, formacie bibliograficznym i objętości druku, języku lub języków tekstu; a także o nakladcy, drukowanej dedykacji; powinna być uwzględniona cytata bibliograficzna potwierdzająca przeprowadzenie identyfikacji oraz sygnatura obiektu pochodzącego z określonych zbiorów.

W dalszych rubrykach karty dokumentacyjnej rejestrowane są fakty dotyczące charakterystycznych cech danego druku: użytego papieru (jednorodny, mieszany, cienki, gruby, welinowy, żeberkowany, filigranowy, kolor); kroju zastosowanych czcionek (antykwa, kursywa, szwabacha, fraktura, inne); występowania elementów morfologicznych druku (karta tytułowa, frontispice, sygnet, incipit liber, kolofon, kustosze, sygnatury, foliowanie, paginacja, regestry, inne); układu tekstu drukowanego (blokowy, dwukolumnowy, modus modernus, pagina fracta, interlinia, marginalia, glossy); sposobu zdobienia (winiety, inicjaly, inne); występowania ilustracji, map, planów, nut, tablic, tabel oraz techniki zdobienia (drzeworyt, miedzioryt, inna). Występowanie zgodnych z użytymi terminami faktów zaznaczyć można podkreśleniem. Fakty inne należy nazwać lub opisać. Dla zaobserwowanych faktów o znaczeniu szczególnym warto tworzyć (załącznikową do karty) dokumentację fotografíczną. Oprawę wydawniczą należy opisać katalogowo; inną natomiast określić, podając rodzaj i wiek pochodzenia. Treść rubryk może być rozszerzona stosownie do potrzeb badawczych.

$\mathrm{Na}$ podstawie analizy tych informacji faktograficznych można formulować wnioski dotyczące występowania określonej tendencji stylistycznej w uprawianej przez drukarza sztuce lub też dotyczące trwałości anachronicznych umiejętności w tym zakresie albo o posiadaniu przez typografa przestarzałego wyposażenia warsztatu. Prowadzone w ten sposób badania szczegółowe twórczości poszczególnych drukarzy oraz ciagłości występowania określonych zjawisk w czarnej sztuce lub też poczynione obserwacje zachodzących zmian - wzbogacone wynikami badań dokumentów archiwalnych - pozwolą na formulowanie wniosków uogólniających, niezbędnych dla tworzenia ujęć syntetycznych. 


\section{Przypisy}

' J. Wojakowski, Tylulatura druków staropolskich, w: Opuscula Polonica et Russica, t. 5. Warszawa 1997, s. 5-12.

2 J. Pachoński, Znierzch sławetnych, Kraków 1956, s. 211-218; K. Korotajowa, Przeobrażenia organizacyjne warszawskich zaktadów graficznych w okresie staropolskim, „Roczniki Biblioteczne” 29, 1985, z. 1/2, s. 145-163; M. Cubrzynska-Leonarczyk, Sztuka typograficzna dawnej Warszawy. Katalog Wystawy Biblioteki Uniwersyteckiej w Warszawie, Warszawa 1978.

${ }^{3}$ J. Pachoński, op.cit., s. 41-42.

${ }^{4}$ ibidem, s. 298-305.

${ }^{5}$ ibidem, s. 304.

${ }^{6}$ A. Kawecka-Gryczowa, Dzieje "drukarni latajacej”, „Rocznik Biblioteki Narodowej” 7, 1971, s. $355-376$.

${ }^{7}$ J. Sójka, Jan Rossowski i jego drukarnia, „Roczniki Biblioteczne” 7, 1963, s. 282.

${ }^{8}$ por. Prasa polska w latach 1661-1864, red. J. Łojek, Warszawa 1976, s. 13-15, 11.1.

${ }^{9}$ M. Polakowska, Warszawskie i krakowskie druki urzędowe wXVIII wieku. Studium księgoznawcze, w: Z Badań Nad Polskimi Księgozbiorami Historycznymi, t. 11, Warszawa 1991, s. 27-75.

${ }^{10} \mathrm{~K}$. Korotajowa, Drukarz i lawnik warszawski Jan Trelpiński, w: Warszawa XVI-XVIII w., z. 2, Warszawa 1977, s. 210; L. Gocel, Elert Piotr , w: Stownik pracowników ksiqżki polskiej, red. I. Treichel, Warszawa 1972, s.202; M. Cubrzyńska-Leonarczyk, op.cit., s.13-14.

${ }^{11}$ K. Korotajowa, Schreiber Karol Ferdynand, w: Słownik pracowników ksiqżki polskiej.., s. 801; S. Mossakowski, Tylman z Gameren, ibidem, s. 918.

I2 J. Wojakowski, Wptyw Sejmu Czteroletniego na rozwój drukarsiwa warszasskiego, w: Z Badan Nad Polskimi Księgozbiorami Historycznymi, tom specjalny: Bibliologia dyscypliną integrująca, Warszawa 1993, s. $41-46$.

${ }^{13}$ J. Winiarska-Czaplicka, Papier druków thoczonych na Mazowszu i Podlasiu w XVI-XVIII w. , w: „Kwartalnik Historii Kultury Materialnej” 25, 1977, nr 2, s. 217-242.

${ }^{14}$ H. Widacka, Marstaller. Nadworny sztycharz Stanistawa Augusta, Warszawa 1996; por. rec. J. Wojakowski, Nadworny sztycharz, „Nowe Książki” 1997, nr 6, s. 47.

${ }^{15}$ J. Wojakowski, Wptyw Sejmu ..., s. 44-45.

${ }^{16}$ por. J. Wojakowski, Kolekcja jako źródto historyczne, w: Ogólnopolskie seminarium i warsztaty na temat ochrony zbiorów zabytkowych w regionie, Cieszyn 20-22 września 1995, Materiaby, Cieszyn 1995, s. 22-31. 


\section{Karta dokumentacyjna}

Drukarz

Data druku

Miejsce druku

A. [Autor, tytuł skrócony, format bibliograficzny, objętość] [Język tekstu]

B. [Nakladca] C. [Dedykacja drukowana]

D. [Cytat bibliograficzny]

E. [Sygnatura obiektu]

F. [Papier]: jednorodny, mieszany, cienki, gruby, welinowy, żeberkowany, filligranowy, kolor

G. [Krój czcionki]: antykwa, kursywa, szwabacha, fraktura, inna

H. [Elementy morfologiczne druku] I. [Ukkad tekstu]

karta tytulowa blokowy

frontispice dwukolumnowy

sygnet modus modernus

„incipit liber" pagina fracta

kolofon interlinia

kustosze marginalia

foliowanie glossy

paginacja

regestry

inne

J. [Sposób zdobienia]

K. [Technika zdobienia]

winiety drzeworyt

inicjały

miedzioryt

inne

inna

L. ilustracje

plany

tablice

mapy

nuty

tabele

M. [Opis oprawy wydawniczej; inną oprawę - określić, podając rodzaj i wiek pochodzenia] 